\title{
Redox proteomic study of Bacillus cereus thiol proteome during fermentative anaerobic growth
}

\author{
Fella Hamitouche ${ }^{1}$, Jean-Charles Gaillard ${ }^{2}$, Philippe Schmitt', Jean Armengaud ${ }^{2}$, Catherine Duport ${ }^{1 \dagger}$ and \\ Luc Dedieu ${ }^{1 * \dagger}$
}

\begin{abstract}
Background: Bacillus cereus is a notorious foodborne pathogen, which can grow under anoxic conditions. Anoxic growth is supported by endogenous redox metabolism, for which the thiol redox proteome serves as an interface. Here, we studied the cysteine (Cys) proteome dynamics of B. cereus ATCC 14579 cells grown under fermentative anoxic conditions. We used a quantitative thiol trapping method combined with proteomics profiling.

Results: In total, we identified 153 reactive Cys residues in 117 proteins participating in various cellular processes and metabolic pathways, including translation, carbohydrate metabolism, and stress response. Of these reactive Cys, 72 were detected as reduced Cys. The B. cereus Cys proteome evolved during growth both in terms of the number of reduced Cys and the Cys-containing proteins identified, reflecting its growth-phase-dependence. Interestingly, the reduced status of the $B$. cereus thiol proteome increased during growth, concomitantly to the decrease of extracellular oxidoreduction potential.

Conclusions: Taken together, our data show that the B. cereus Cys proteome during unstressed fermentative anaerobic growth is a dynamic entity and provide an important foundation for future redox proteomic studies in $B$. cereus and other organisms.
\end{abstract}

Keywords: Bacillus cereus, Thiol proteome, Anaerobiosis, Fermentative growth, Differential labeling strategy

\section{Background}

Bacillus cereus is a Gram positive bacterium, which is recognized as a major foodborne pathogen responsible for two types of syndrome: emetic and diarrheal [1]. As well as being a facultative anaerobe, B. cereus can adapt to a wide range of environmental conditions allowing it to multiply in a number of food products and in the human intestine $[2,3]$. In these environments, B. cereus adapts its metabolism to variations in temperature [4], $\mathrm{pH}$, oxygen level, and oxidoreduction potential (ORP)

\footnotetext{
* Correspondence: luc.dedieu@univ-avignon.fr

${ }^{\dagger}$ Catherine Duport and Luc Dedieu should be considered as co-last authors. ${ }^{1}$ Avignon Université, INRAE, UMR SQPOV, Site Agroparc, F-84914 Avignon Cedex 9, France

Full list of author information is available at the end of the article
}

[2]. B. cereus uses aerobic respiratory pathways to grow under aerobiosis, and mixed acid fermentation pathways to grow under anaerobiosis in the absence of an external electron acceptor. The main product of fermentation is lactate, which is synthesized alongside acetate, ethanol, formate, succinate, and small amounts of 2, 3-butanediol [5]. B. cereus re-oxidizes the reducing equivalent NADH, generated by glucose catabolism from $\mathrm{NAD}^{+}$, through the respiratory chain under aerobiosis, and during the formation of end-products under anaerobiosis [6]. Thus, $\mathrm{NAD}^{+} / \mathrm{NADH}$ is central to catabolism and energy supply, whereas the $\mathrm{NADP}^{+} / \mathrm{NADPH}$ couple plays an important role in biosynthesis and detoxification of cells [7]. Consequently, both the NAD and NADP systems

(c) The Author(s). 2021 Open Access This article is licensed under a Creative Commons Attribution 4.0 International License, which permits use, sharing, adaptation, distribution and reproduction in any medium or format, as long as you give appropriate credit to the original author(s) and the source, provide a link to the Creative Commons licence, and indicate if changes were made. The images or other third party material in this article are included in the article's Creative Commons licence, unless indicated otherwise in a credit line to the material. If material is not included in the article's Creative Commons licence and your intended use is not permitted by statutory regulation or exceeds the permitted use, you will need to obtain permission directly from the copyright holder. To view a copy of this licence, visit http://creativecommons.org/licenses/by/4.0/ The Creative Commons Public Domain Dedication waiver (http://creativecommons.org/publicdomain/zero/1.0/) applies to the data made available in this article, unless otherwise stated in a credit line to the data. 
play major roles in redox homeostasis [8]. Lowmolecular weight compounds, such as coenzyme A, free cysteines, and bacillithiol (BSH) are also major contributors to redox homeostasis [9], in particular through their regulation of the redox status of the two amino-acids containing thiol $(\mathrm{SH})$ groups, methionine (Met) and cysteine (Cys). Together, Cys and Met fulfill important roles in cells thanks to their redox chemistry [10]. Although the two residues are subject to redox regulation, the thioether form of the Met sulfur atom is less reactive than the sulfhydryl (thiol, $\mathrm{SH}$ ) form of the Cys sulfur atom [10].

The redox status of $\mathrm{Cys} \mathrm{SH}$ in proteins contributes significantly to protein folding [11], metal binding [12], and regulating protein function [10]. Thus, oxidation of Cys $\mathrm{SH}$ groups can result in the formation of reversible modifications such as disulfide bridges (S-S), sulfenic acid $(\mathrm{S}-\mathrm{OH})$ and nitrosylation (-SNO) groups, and irreversible oxidations such as sulfinic $\left(\mathrm{R}-\mathrm{SO}_{2} \mathrm{H}\right)$ and sulfonic acid $\left(\mathrm{R}-\mathrm{SO}_{3} \mathrm{H}\right)$ species [10]. The set of proteins containing reversibly modified thiols is referred to as the thiol proteome [13], or redoxome [14].

Attempts to study the thiol proteome have taken several approaches. Due to their high lability, cysteine modifications are challenging to analyze. Methods to identify Cys redox modifications have progressed over the years, ranging from the estimation of $\mathrm{SH}$ groups using colorimetric tests [15], and monitoring protein cysteine oxidation by loss of reactivity with thiol reagents [16], to accurately identifying sites of thiol redox modifications in numerous proteins [17]. The differential thiol labeling method constituted a major advance in the depth of analysis possible. The first step involves irreversibly blocking reduced-Cys thiols with an alkylating agent, subsequently the oxidized thiols are reduced, and finally labeled with a different alkylating agent [17]. This method has been combined with $2 \mathrm{D}$ gel-based methods $[18,19]$ to identify several redox-sensitive proteins. However, this combination presented limitations, mainly in the identification of cysteines. Today, the combination of differential thiol labeling with tandem mass spectrometry is a powerful means to overcome the limitations of previous methods and to provide broad coverage of the thiol proteome [14]. At the proteome level, reduced and oxidized Cys can be distinguished thanks to the use of different alkylating agents [13]. They can thus be quantified and the abundance of the proteins bearing these residues can be estimated [20].

Large-scale redox proteomic analysis has been used to investigate the relationships between the thiol proteome status in (i) cyanobacteria, focusing on photosynthesis and the response to nutrient limitation [21, 22], and (ii) Clostridium difficile [23], Saccharomyces cerevisiae [24], Escherichia coli [25, 26], and Firmicutes including
Bacillus subtilis [27], to investigate responses to oxidative stress. These studies revealed that the thiol proteome modifies key biological processes through alterations to redox-sensitive proteins such as the elongation factor EF-Tu (Tuf), a key component of translation [28]; alcohol dehydrogenase (AdhA), which is involved in energy metabolism [23]; and alkyl hydroperoxide reductase $(\mathrm{AhpC})$, a key player in defensive mechanisms [21].

Previous studies investigated the redox status of Met residues in unstressed $B$. cereus cells at both the cellular proteome and exoproteome levels $[29,30]$. However, the thiol proteome of unstressed $B$. cereus cells has not yet been investigated. In this study, we used a thiol trapping method combined with shotgun proteomics analyses to decipher the $B$. cereus thiol proteome during fermentative anaerobic growth. Our results show that the $B$. cereus thiol proteome is growth-phase-dependent and contains higher number of reduced Cys in the later stages of growth.

\section{Results \\ Labeling strategy for global analysis of the $B$. cereus thiol proteome}

Fermentative growth of B. cereus ATCC 14579 is illustrated in Fig. 1. It was accompanied by a decrease in extracellular ORP $(\triangle \mathrm{ORP}=217 \pm 20 \mathrm{mV})$. Culture samples were collected anaerobically, in TCA-containing vials at early- (EEP), mid- (MEP) and late-exponential (LEP) growth phases. Mixing with TCA resulted in immediate lysis of cells and precipitation of proteins, thus preserving the in vivo redox status of proteins containing Cysteine (Cys) residues [31].

Reactive Cys residues were labeled using a three-step sequential strategy as previously described [32], and named IDN in our study (Fig. 2): First, iodoacetamide (IAM) was used to label and block free Cys thiol groups $(\mathrm{SH})$. Then, reversibly-oxidized thiol (S-OX) were reduced by exposure to DTT, and finally the corresponding thiol groups were labeled using $\mathrm{N}$-ethylmaleimide (NEM). The IN control omitted the DTT reduction step, and was used to assess how efficiently IAM blocked Cys $\mathrm{SH}$. All proteins were digested with trypsin, and the resulting peptides were submitted to extensive LC-MS/ MS analysis. A total of 354,684 peptides were identified from the 18 samples ( 3 cultures $\times 3$ time-points $\times 2$ labels), including 9531 Cys-containing peptides. A total of $20,952 \pm 5265,20,274 \pm 4541$, and $16,760 \pm 2880$ peptides were identified at EEP, MEP, and LEP, respectively. These values are not significantly different according to Student's T-test.

The number of IAM-labeled Cys residues (IAMCys) was not significantly different in IDN-treated samples and IN controls, whatever the growth phase (Fig. 3). In 


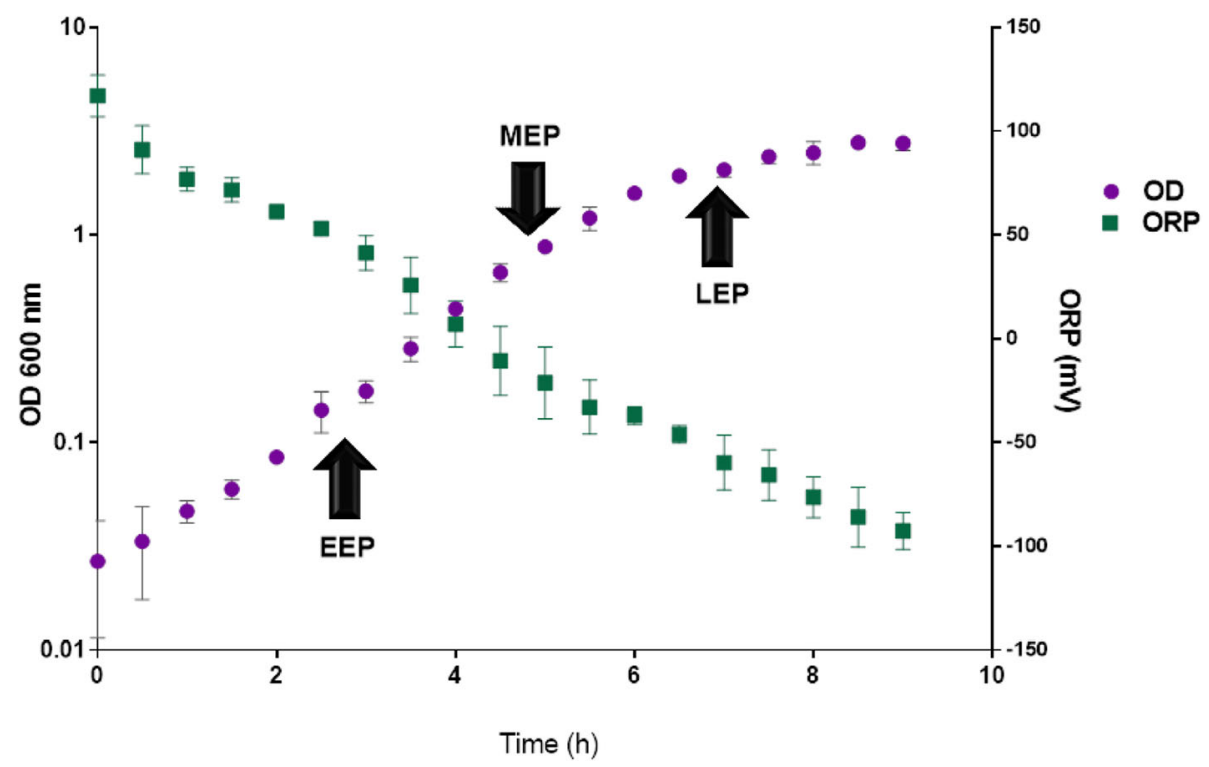

Fig. 1 Growth curve and alterations to extracellular oxidoreduction potential (ORP) of B. cereus ATCC 14579 in regulated anoxic batch cultures. Circles represent optical densities at $600 \mathrm{~nm}\left(\mathrm{OD}_{600}\right)$ and squares correspond to extracellular ORP. Black arrows indicate cell harvesting, at earlyexponential growth phase (EEP), mid-exponential growth phase (MEP), and late-exponential growth phase (LEP). Data correspond to mean values calculated for biological triplicates \pm SD

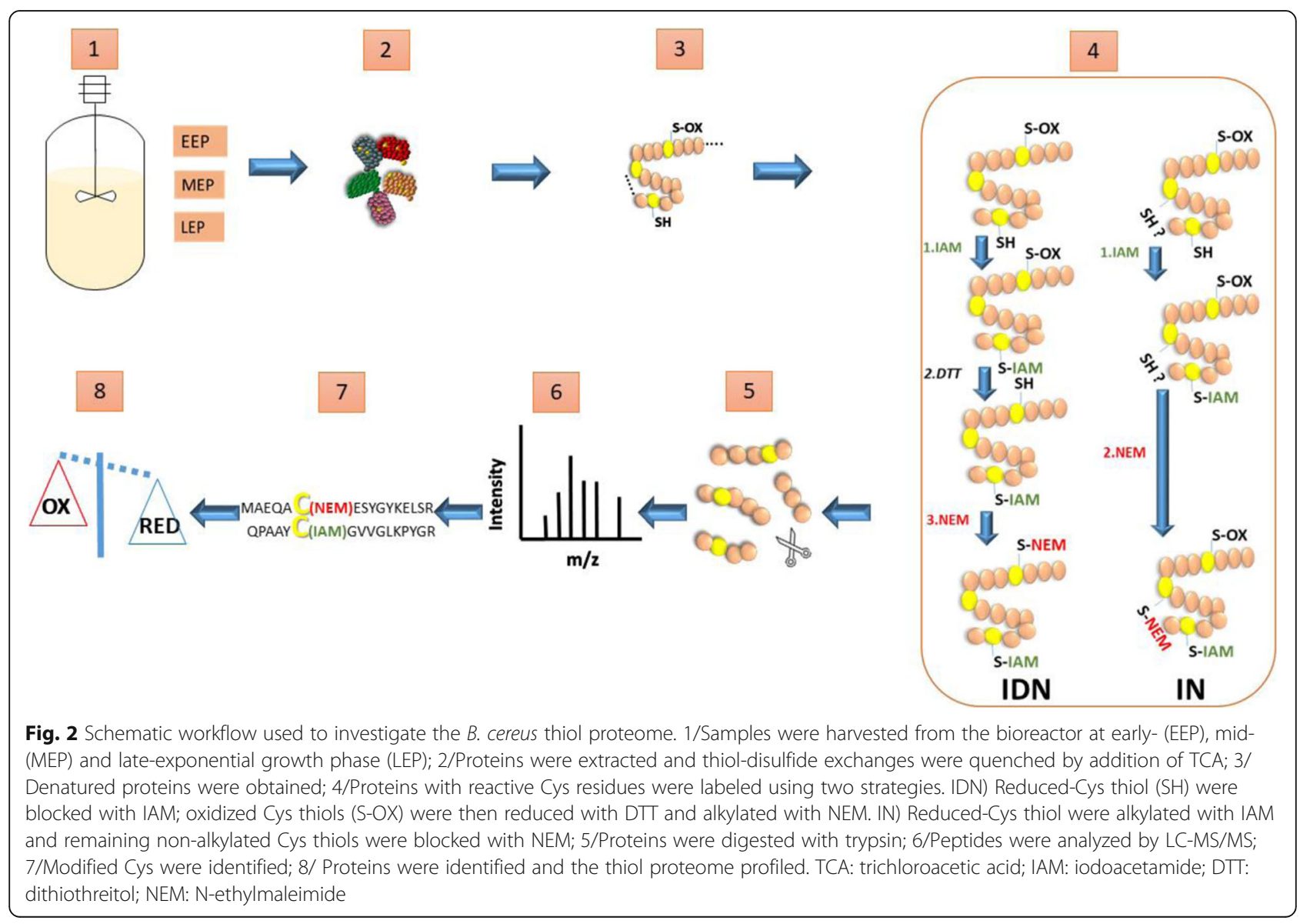




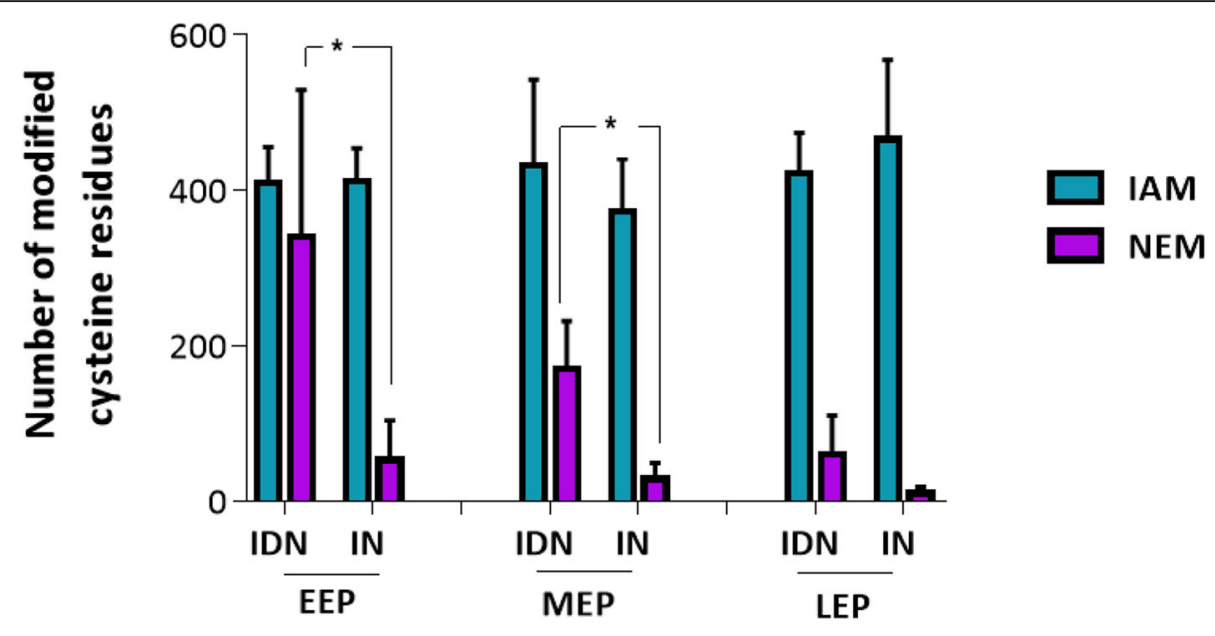

Fig. 3 Labeling efficiency of IDN assay compared to IN control. IDN: reduced Cys were labeled with IAM and reversibly-oxidized Cys were reduced with DTT prior to labeling with NEM. IN: reduced Cys were first labeled with IAM and then with NEM without reduction between steps. The labeled Cys-containing peptides and Cys residues were quantified in samples harvested at early-exponential phase (EEP), mid-exponential phase (MEP) and late-exponential phase (LEP). Data correspond to mean values calculated for triplicates. Error bars show standard deviation. Paired Student t-test was performed to determine statistical significance $\left({ }^{*}: 0.01<p<0.05 ;{ }^{* *}: 0.001<p<0.01 ;{ }^{* * *}: p<0.001\right)$

contrast, as expected, the number of NEM- labeled Cys residues (NEMCys) detected was higher in IDN samples than in the IN control, for samples harvested during the EEP and MEP growth phases. Taken together, these results indicate that IAM alkylation stabilizes free sulfhydryl groups, but that a small number of Cys residues escape IAM alkylation and remain available for alkylation with NEM.

\section{B. cereus thiol proteome dynamics}

NEMCys in IDN samples correspond to either in vivo oxidized Cys or insensitive IAM residues. To retain only in vivo oxidized Cys residues, we corrected the IDN data by subtracting NEMCys detected in the IN dataset from the list of NEMCys detected in the IDN dataset. The corrected IDN dataset (IDNc) is shown in Table S1.

Analysis of the IDNc dataset shows that the numbers of RedCys (labeled with IAM) and OxCys (labeled with NEM after reduction) were significantly different at both MEP and LEP (Fig. 4A). In addition, the number of OxCys residues decreased during growth and the number of RedCys tend to increase as growth progresses. These data suggest that the thiol proteome evolved toward a highly reduced status as growth progressed. Due to trypsin missed cleavage and differences in abundance, some redox-sensitive Cys residues specified the same cysteine site. Removal of this redundancy resulted in a total of 110, 99 and 93 non-redundant (unique) redoxsensitive Cys residues at EEP, MEP and LEP respectively (Table 1). The number of the non-redundant redoxsensitive Cys residues decreased during growth due to an overall decrease in non-redundant peptide detection. This probably reflects the overall regulation of protein synthesis during growth [33]. However, the labeling efficiency remained stable $(3 \pm 0.1 \%$, Table 1$)$.

We compared the numbers of RedCys and OxCys of each non-redundant Cys residue. Based on this analysis, we identified 74 Cys residues for which the mean of RedCys number was significantly different from the mean of OxCys number $(p<0.05)$. Figure 5 shows their growth stage distribution (Fig. 5A), their RedCys vs OxCys distribution and the peptide sequences in which they were identified (Fig. 5B). The data indicate that (i) most of the 74 Cys residues were identified in only one growth phase and only two Cys residues had a higher number of OxCys compared to RedCys: one at EEP and the other at MEP. (ii) LEP samples supported the largest number of Cys residues, and (iii) the 74 Cys residues were contained in 72 non-redundant peptides.

If we consider all the 74 Cys residues, we do not observe any change in the total number of OxCys number during growth. In contrast, we observe a significant increase in the total number of RedCys at MEP and LEP, compared to EEP (Fig. 4B). This overall increase results from an increase in the number of RedCys residues identified in samples from at least two growth stages (hatched bars in Fig. 4B), and RedCys residues identified specifically in samples from only one growth stage (plain bars in Fig. 4B).

\section{Components of the $B$. cereus thiol proteome}

According to our results, the $B$. cereus thiol proteome includes 153 reactive Cys-containing peptides, of which 70 were detected mainly in the reduced form, and 2 in the oxidized form. We assigned these 153 peptides to their corresponding proteins. The resulting set consisted 

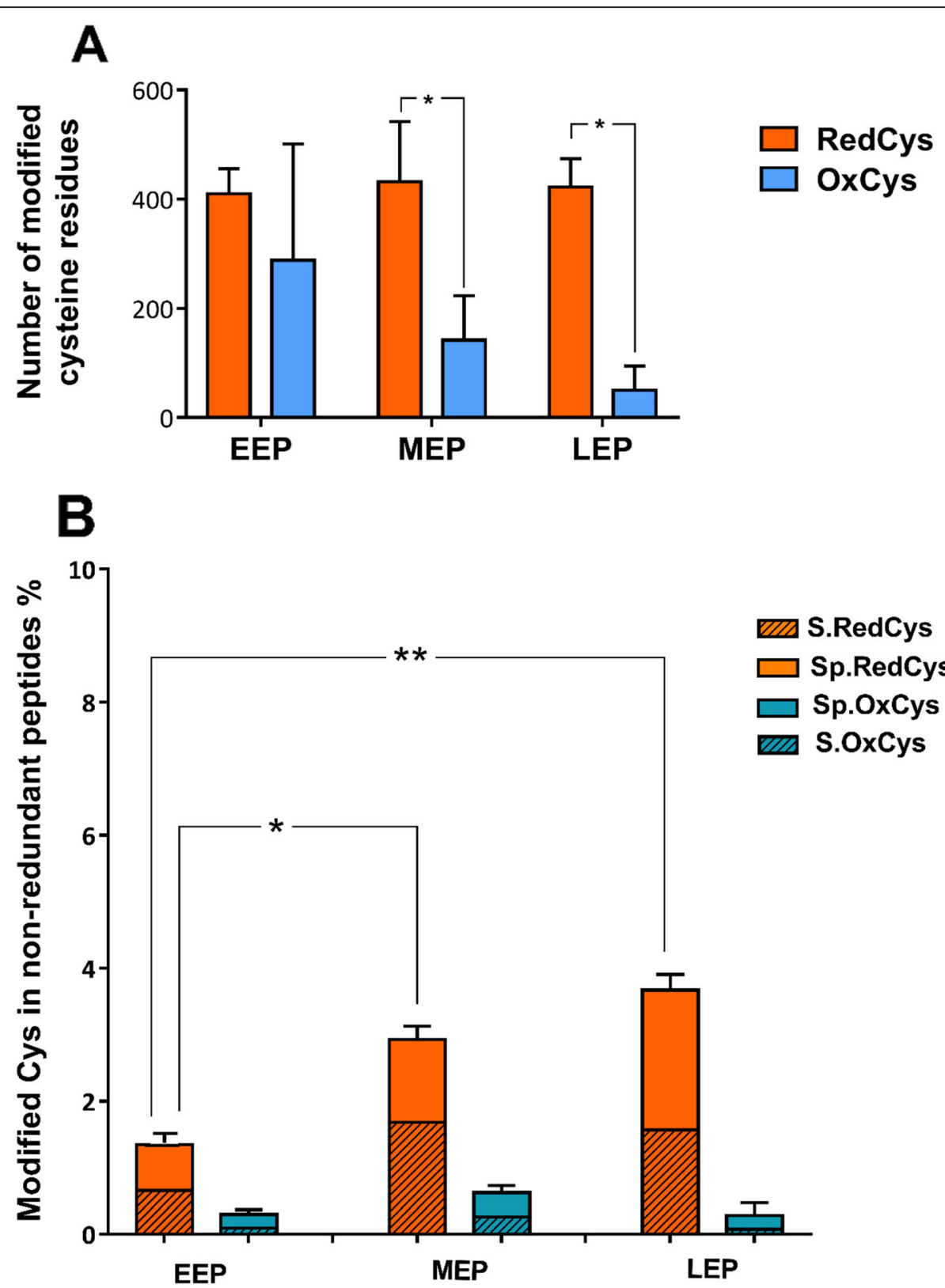

Fig. 4 Proportion of reduced Cys (RedCys) and oxidized Cys (OxCys) residues identified in samples harvested at early-exponential, midexponential and late-exponential growth phases (EEP, MEP, and LEP, respectively). A Number of modified cysteines: RedCys and OxCys in samples. B Proportion of non-redundant RedCys and non-redundant OxCys residues. Sp.RedCys/Sp.Oxcys: reduced/oxidized cysteine residues that have been detected in only one growth stage (these residues are specific to a growth stage); S.RedCys/S.OxCys: reduced/oxidized cysteine residues that have been detected in two or three growth stages. Data correspond to mean values calculated for three replicates. Error bars show standard deviation. Paired Student t-test was performed to determine statistical significance $\left({ }^{*}: 0.01<p<0.05 ;{ }^{* *}: 0.001<p<0.01\right.$; $\left.{ }^{* *}: p<0.001\right)$

of 117 proteins (Table S2), of which 64 contained the 74 Cys residues identified above (Table 2). These proteins were mainly involved in translation, amino acid, nucleotide and carbohydrate metabolism, as well as defense mechanisms, whatever the growth stage (Fig. 6). Proteins related to carbohydrate metabolism include the glycolytic enzymes phosphofructokinase PfkA (Q817F3) and phosphoenolpyruvate
PtsI (Q819D7), the fermentative enzyme pyruvate formate-lyase PflA (Q81IA2), and alcohol dehydrogenase (AdhA, Q81DX6), which also plays an important role in fermentative metabolism. Three distinct modified cysteines were identified in AdhA: $\mathrm{Cys}^{255}$ was mainly detected as RedCys at MEP, whereas the two others $\left(\mathrm{Cys}^{97}\right.$ at EEP and $\mathrm{Cys}^{91}$ at $\mathrm{MEP}$ ) were mainly detected as OxCys. 
Table 1 Numbers of non-redundant peptides, Cys-containing peptides and Cys residues identified in all the three replicates at early-exponential phase (EEP), mid-exponential phase (MEP) and late-exponential phase (LEP)

\begin{tabular}{llll}
\hline & EEP & MEP & LEP \\
\hline Non-redundant peptides & 3673 & 3330 & 3087 \\
Non-redundant Cys-peptides & 109 & 95 & 88 \\
Non-redundant Cys residues & 110 & 99 & 93 \\
\hline
\end{tabular}

Several proteins were categorized in functional groups related to defense mechanisms. Superoxide dismutase SodA2 (Q814I6) contains a Cys residue $\left(\mathrm{Cys}^{60}\right)$ identified as redox-sensitive at MEP, this protein was more abundant during LEP than during EEP (Table S2). The abundance of catalase (Kat, Q81GN6) increased during the LEP compared to both EEP and MEP, it harbors two redox-sensitive residues, $\mathrm{Cys}^{357}$, which are mainly detected as RedCys both at MEP and LEP; and Cys ${ }^{458}$, which is mainly detected as RedCys both at EEP and LEP. Thiol peroxidase (Tpx, Q817B8) contains two redox-sensitive Cys residues $\left(\mathrm{Cys}^{60}\right.$ and $\mathrm{Cys}^{94}$ ), indifferently detected as RedCys and OxCys throughout growth. Finally, alkyl hydroperoxide reductase $\mathrm{C}$ (AhpC, Q81IK9) contains one Cys residue $\left(\mathrm{Cys}^{166}\right)$, which was identified as redox-sensitive in the three growth stages, and mainly detected as RedCys at LEP.

Among the proteins categorized in the translationrelated functional group, three are known to bind tRNA. These proteins harbored RedCys residues at EEP and MEP: Cys $^{170}$ in PheT1 (Q812N7), Cys ${ }^{124}$ in IleS1 (Q819R4) and $\mathrm{Cys}^{153}$ in ArgS (Q814Q8). The elongation factor FusA (Q814C5) contains a Cys residue $\left(\mathrm{Cys}^{258}\right)$ that was mainly detected as RedCys at EEP. The elongation factor Tuf (Q814C4) was associated with two redox-sensitive Cys residues $\left(\mathrm{Cys}^{82}\right.$ and $\mathrm{Cys}^{138}$ ), which were mainly detected as RedCys at MEP and LEP, respectively.

Several proteins involved in nucleotide metabolism were identified in our study, these included PurD (Q81IP8), Adk (Q81J22) and GuaB (Q81JC8). Interestingly, the three Cys residues present in Inosine-5'monophosphate dehydrogenase (GuaB) were found to be redox-sensitive at all three growth stages: $\mathrm{Cys}^{308}$, which contributes to the active site, indifferently detected as RedCys and OxCys throughout growth, whereas Cys ${ }^{446}$ was detected as RedCys at all three growth phases, and $\mathrm{Cys}^{327}$ was detected mainly as RedCys specifically at LEP.

Five proteins involved in amino acid metabolism were also identified. TrpA (Q81GG4), TrpB (Q81GG5), TrpC (Q81GG7), and PabA (Q81GG9). These proteins were more abundant in samples harvested at LEP compared to both EEP and MEP. Anthranilate synthase component I TrpE (Q81GH0) was more abundant at LEP than at MEP (Table 2).

In addition to these classes of proteins, we identified RedCys residues in iron-sulfur cluster proteins such as NifU (Q816B6), which is involved in the biogenesis of bacterial Fe/S proteins, and is thus responsible for several functions, including redox catalysis [34]. The abundance of NifU increased significantly during LEP compared to EEP and MEP.

Interestingly, based on Cys-peptides and spectral count analysis, we detected three proteins involved in the assembly of the bacillibactin siderophore during the LEP. These proteins, the isochorismate synthase DhbC (Q81DQ3), the isochorismatase DhbB (Q81DQ1) and the 2,3-dihydroxybenzoate-AMP ligase DhbE (Q81DQ2) were only detected in samples harvested during the LEP. In DhbE, Cys ${ }^{473}$ was indifferently detected as RedCys and OxCys. DhbB harbors two Cys residues, $\mathrm{Cys}^{67}$ and $\mathrm{Cys}^{197}$, indifferently detected as RedCys and OxCys. In contrast, Cys ${ }^{14}$ in DhbC was mainly detected as RedCys.

\section{Discussion}

Thiol redox modifications play important roles in regulating proteins that sustain bacterial growth. However, despite its importance, and mainly due to technical challenges, few studies have attempted to quantify changes in the bacterial thiol redox proteome during growth. The first hurdle relates to the extreme sensitivity of Cys residues to artefactual oxidation. For our study, we circumvented this problem by performing rapid quenching with TCA [35]. A second challenge is to use an efficient strategy to profile thiol redox modifications in the whole organism. We adopted a strategy without peptide enrichment steps to avoid introducing quantitative bias which could lead to deviations from physiological conditions, as we wished to conserve the situation in the cell at the time of harvesting as far as possible. To achieve our aims, we implemented a differential thiol trapping technique, the IDN strategy, which relies on irreversible modifications of reduced Cys residues by IAM, and oxidized Cys residues by NEM after DTT treatment $[32,36]$. This strategy does not make it possible to characterize the OxCys forms, and to establish if they are part of an inter- or intra-polypeptide disulfide.

In any differential labeling strategy, the first alkylation - to block free thiols - must be highly efficient. Indeed, incomplete alkylation would increase the number of Cys available for NEM-labeling, leading to incorrect identification of oxidized residues [17]. In a previous study, Shakir et al. [25] used a sulfhydryl reactive dye (DyLight 550 maleimide) to estimate the proportion of free thiols after IAM labeling as a means to assess the efficiency of IAM alkylation. Here, we included a control sample (IN) 
A

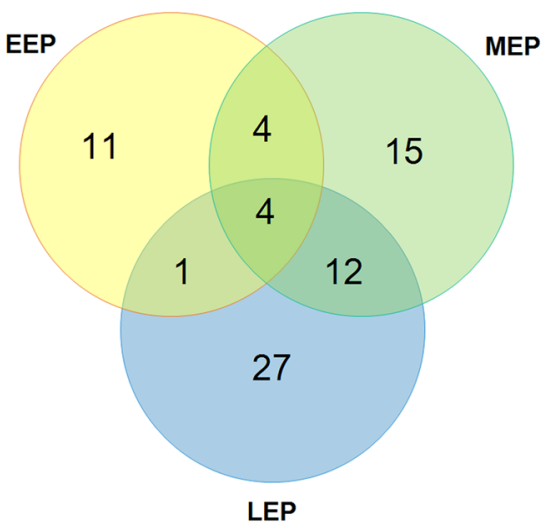

B

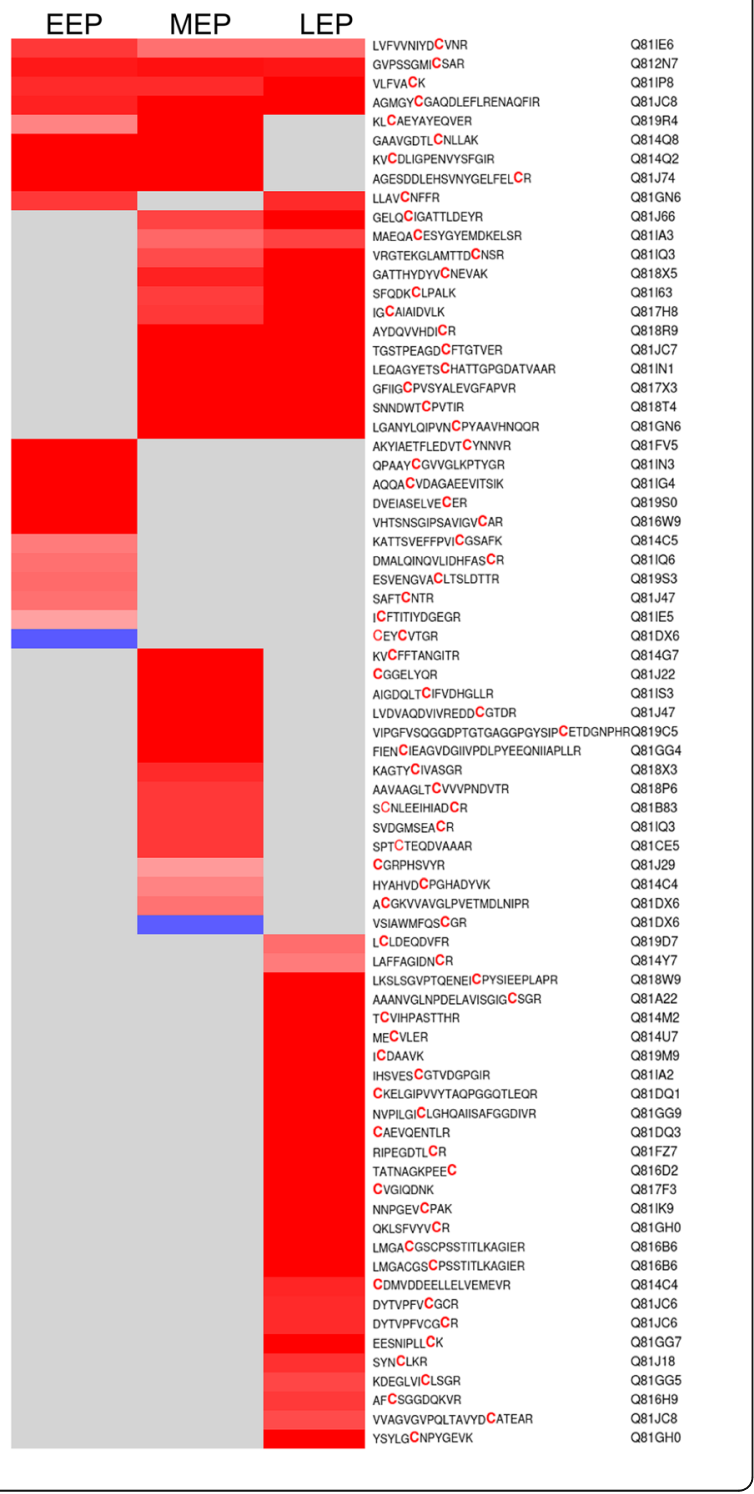

Fig. 5 Growth-phase-distribution of the 74 Cys residues detected predominantly either as reduced Cys (RedCys) or as oxidized Cys (OxCys). A Venn diagram showing the growth-phase-distribution of the $74 \mathrm{Red} / \mathrm{OxCys}$ residues. B Heat map visualization of the 72 peptides containing the $74 \mathrm{Red} / \mathrm{OxCys}$ residues. EEP, earlyexponential growth phase; MEP, mid-exponential growth phase; LEP, late-exponential growth phase. Colors represent the redox form that predominates. Blue: oxidized form; red: reduced form; gray: no significant difference

to demonstrate and precisely quantify how efficiently IAM blocked free thiols. We were thus able to correct the data and obtain accurate quantifications of the NEMCys target. Through our approach, we identified 153 reactive Cys residues in B. cereus thiol proteome. This relatively low number of redox-target Cys may be explained by the overall low Cys content of proteins in $B$. cereus (less than 1\%) [23]. Like the other facultative anaerobic Gram positive Firmicutes, B. cereus probably promotes cysteine exclusion from both its cytoplasmic and exported proteins due to their high sensitivity to reactive oxygen and nitrogen species (ROS and RNS) [37]. Indeed, any such sensitivity could pose problems for an organism that can survive in a wide variety of, sometimes hostile, environments. Another possibility is that by restricting our analysis to Cys residues identified in all three replicates at each stage of growth to ensure the data generated were reliable and reproducible, we may have excluded some redox-sensitive Cys residues. However, our results are of the same order of magnitude as those reported for Caenorhabditis elegans, for which fewer than 200 redox-sensitive Cys residues were identified during its lifespan [38].

Our study revealed that the number of detected reduced Cys residues increased as growth progressed. Extracellular ORP decreased at the same time, thus $B$. cereus growth under anaerobiosis is accompanied by a significant decrease in extracellular ORP, especially between the beginning and the end of exponential growth [29]. The ability to decrease extracellular ORP is common to many bacteria, and may be related to the consumption of oxidizing compounds or the production of reducing end-products, as reported for $E$. coli [39]. In Lactococcus lactis and Listeria monocytogenes the decrease in extracellular ORP has been shown to depend on the presence of reduced thiol groups present on proteins located at the bacterial cell surface $[40,41]$. If the number of reduced thiol groups of these proteins increases as growth progresses, as in the case of the thiol groups in the proteins identified in this study, it could drive the reduction in extracellular ORP. However, this hypothesis will need to be proven through future research. 
Table 2 Cys-proteins harboring specific cysteines detected as RedCys or as OxCys

\begin{tabular}{llll}
\hline Cys position & Protein & Description & $\frac{\text { Log }_{2}(\mathrm{FC})}{\text { EEP/LEP }}$ \\
\hline
\end{tabular}

Cys proteins in EEP,MEP,LEP

Nucleotide metabolism

Q81IP8 $\quad 381$

PurD

Q81JC8

446

GuaB

TerD

PheT_1

170

Q812N7

123

\section{Q81IE6}

\section{Cys proteins in EEP,MEP}

Cofactors and vitamins metabolism

$$
\text { Q81J74 }
$$

Translation

$\begin{array}{ll}\text { Q819R4 } & 124 \\ \text { Q814Q8 } & 153\end{array}$

Amino acid metabolism
Q814Q2
159

\section{Cys proteins in EEP,LEP}

Defense mechanisms
Q81GN6
458

Cys proteins in MEP,LEP

Nucleotide metabolism

$\begin{array}{ll}\text { Q817X3 } & 64 \\ \text { Q81IQ3 } & \underline{464}\end{array}$

Carbohydrate metabolism

$\begin{array}{ll}\text { Q818T4 } & 111 \\ \text { Q81IA3 } & 123\end{array}$

Cofactors and vitamins metabolism

$\begin{array}{lll}\text { Q818X5 } & \underline{92} & \text { RibH } \\ \text { Q818R9 } & 405 & \text { Dxs }\end{array}$

Amino acid metabolism

Q817H8 189

Lipid and Fatty acid metabolism

Q81IN1

Pathogenesis

Q81163 $\quad \frac{184}{266}$

Defense mechanisms
Q81GN6
357

Transcription

Q81J66

Kat

$\mathrm{MecB}$ lles1

ArgRS

SpeB

Kat

Apt

PurL

Dxs

s

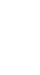

7,8-dihydroneopterin aldolase

Isoleucine-tRNA ligase 1

Arginine-tRNA ligase

Agmatinase

NS

$-2,46$

$-1,93$

Catalase

Adenine phosphoribosyltransferase

NS

NS

synthase subunit

2-oxoisovalerate dehydrogenase

beta subunit

Formate acetyltransferase

NS

NS

6,7-dimethyl-8-ribityllumazine synthase

1-deoxy-D-xylulose-5-phosphate synthase

Deblocking aminopeptidase

NS

NS

DAGKc domain-containing protein

NS

NS

Microbial collagenase

D-alanyl-D-alanine carboxypeptidase

NS

NS

$-2,46$

$-1,93$

Catalase

Negative regulator of genetic competence

NS $\quad$ NS

NS NS
NS

NS
NS

NS

NS

NS 
Table 2 Cys-proteins harboring specific cysteines detected as RedCys or as OxCys (Continued)

\begin{tabular}{|c|c|c|c|c|c|}
\hline \multirow{2}{*}{\multicolumn{2}{|c|}{ Cys position }} & \multirow[t]{2}{*}{ Protein } & \multirow[t]{2}{*}{ Description } & \multicolumn{2}{|l|}{$\log _{2}(F C)$} \\
\hline & & & & EEP/LEP & MEP/LEP \\
\hline \multicolumn{6}{|c|}{ Cys proteins in EEP } \\
\hline \multicolumn{6}{|c|}{ Nucleotide metabolism } \\
\hline Q81।Q6 & 169 & PurC & $\begin{array}{l}\text { Phosphoribosylaminoimidazole- } \\
\text { succinocarboxamide synthase }\end{array}$ & NS & NS \\
\hline Q819S3 & 1034 & CarB & $\begin{array}{l}\text { Carbamoyl-phosphate synthase } \\
\text { large chain }\end{array}$ & NS & NS \\
\hline Q819S0 & 264 & PyrB & Aspartate carbamoyltransferase & NS & NS \\
\hline Q81FV5 & 38 & DeoD & Purine nucleoside phosphorylase & NS & NS \\
\hline \multicolumn{6}{|l|}{ Translation } \\
\hline Q81IN3 & 185 & GatA & $\begin{array}{l}\text { Glutamyl-tRNA (Gln) amidotransferase } \\
\text { subunit A }\end{array}$ & NS & NS \\
\hline Q814C5 & 258 & FusA & Elongation factor $\mathrm{G}$ & NS & NS \\
\hline \multicolumn{6}{|c|}{ Transcription } \\
\hline Q81J47 & 892 & RpoC & $\begin{array}{l}\text { DNA-directed RNA polymerase } \\
\text { subunit beta }\end{array}$ & NS & NS \\
\hline \multicolumn{6}{|c|}{ Amino acid metabolism } \\
\hline Q816W9 & 315 & & Deblocking aminopeptidase & NS & NS \\
\hline \multicolumn{6}{|c|}{ Defense mechanisms } \\
\hline Q81IE5 & 110 & TerD & Tellurium resistance protein & NS & NS \\
\hline \multicolumn{6}{|c|}{ Function unknown } \\
\hline Q81IG4 & 65 & & $\begin{array}{l}\text { Thiamine_BP domain-containing } \\
\text { protein }\end{array}$ & NS & NS \\
\hline \multicolumn{6}{|c|}{ Carbohydrate metabolism } \\
\hline Q81DX6 & 97 & AdhA & Alcohol dehydrogenase & NS & NS \\
\hline \multicolumn{6}{|c|}{ Cys proteins in MEP } \\
\hline \multicolumn{6}{|c|}{ Nucleotide metabolism } \\
\hline Q81J22 & 153 & Adk & Adenylate kinase & NS & NS \\
\hline Q81IS3 & 250 & GuaA & GMP synthase & NS & NS \\
\hline Q81IQ3 & 527 & PurL & $\begin{array}{l}\text { Phosphoribosyl formylglycinamidine } \\
\text { synthase subunit }\end{array}$ & NS & NS \\
\hline \multicolumn{6}{|l|}{ Translation } \\
\hline Q814G7 & 15 & RpsR & 30 S ribosomal protein $\$ 18$ & NS & NS \\
\hline Q81J29 & 27 & RpsZ & 30 S ribosomal protein S14 type Z & NS & NS \\
\hline Q814C4 & 82 & Tuf & Elongation factor Tu & NS & NS \\
\hline \multicolumn{6}{|c|}{ Transcription } \\
\hline Q81J47 & 818 & RpoC & $\begin{array}{l}\text { DNA-directed RNA polymerase } \\
\text { subunit beta }\end{array}$ & NS & NS \\
\hline Q81CE5 & 158 & PpaC & $\begin{array}{l}\text { Probable manganese-dependent } \\
\text { inorganic pyrophosphatase }\end{array}$ & NS & NS \\
\hline \multicolumn{6}{|c|}{ Amino acid metabolism } \\
\hline Q81GG4 & 115 & TrpA & Tryptophan synthase alpha chain & -3.08 & -2.14 \\
\hline \multicolumn{6}{|c|}{ Carbohydrate metabolism } \\
\hline Q818P6 & 194 & & Phosphoglycolate phosphatase & NS & NS \\
\hline Q81DX6 & $91 / 255$ & AdhA & Alcohol dehydrogenase & NS & NS \\
\hline \multicolumn{6}{|c|}{ Cofactors and vitamins metabolism } \\
\hline Q818X3 & 115 & Biob & Biotin synthase & NS & NS \\
\hline
\end{tabular}


Table 2 Cys-proteins harboring specific cysteines detected as RedCys or as OxCys (Continued)

\begin{tabular}{|c|c|c|c|c|c|}
\hline \multirow[t]{2}{*}{+2} & \multirow[t]{2}{*}{ Cys position } & \multirow[t]{2}{*}{ Protein } & \multirow[t]{2}{*}{ Description } & \multicolumn{2}{|l|}{$\log _{2}(F C)$} \\
\hline & & & & EEP/LEP & MEP/LEP \\
\hline \multicolumn{6}{|c|}{ Protein folding } \\
\hline Q819C5 & 73 & & Peptidyl-prolyl cis-trans isomerase & NS & NS \\
\hline \multicolumn{6}{|c|}{ Cys proteins in LEP } \\
\hline \multicolumn{6}{|c|}{ Amino acid metabolism } \\
\hline Q81GG5 & 378 & $\operatorname{TrpB}$ & Tryptophan synthase beta chain & $-2,24$ & $-2,26$ \\
\hline$\underline{\mathrm{Q} 81 \mathrm{GH} 0}$ & $\underline{168 / 65}$ & TrpE & Anthranilate synthase component 1 & $-2,17$ & $-2,17$ \\
\hline$\underline{\text { Q81GG7 }}$ & 108 & TrpC & Indole-3-glycerol phosphate synthase & $-2,55$ & $-2,26$ \\
\hline$\underline{\text { Q81GG9 }}$ & $\underline{62}$ & PabA (TrpGD) & Anthranilate synthase component II & $-1,93$ & $-1,39$ \\
\hline$\underline{\mathrm{Q} 814 \mathrm{M} 2}$ & 364 & & O-acetylhomoserine sulfhydrylase & NS & NS \\
\hline \multicolumn{6}{|c|}{ Carbohydrate metabolism } \\
\hline Q819M9 & $\underline{262}$ & & Pyruvate carboxylase & NS & NS \\
\hline Q81FZ7 & 124 & & Glycerate dehydrogenase & NS & NS \\
\hline Q81A22 & $\underline{50}$ & PorB & Pyruvate synthase subunit & NS & NS \\
\hline Q81IA2 & $\underline{12}$ & PflA & Pyruvate formate lyase activating enzyme & NS & NS \\
\hline Q817F3 & $\underline{283}$ & PfkA & ATP-dependent 6-phosphofructokinase & NS & NS \\
\hline Q819D7 & $\underline{365}$ & Ptsı & $\begin{array}{l}\text { Phosphoenolpyruvate-protein } \\
\text { phosphotransferase }\end{array}$ & NS & NS \\
\hline \multicolumn{6}{|c|}{ Cofactors and vitamins metabolism } \\
\hline Q81JC6 & $\underline{128 / 130}$ & PdxS & Pyridoxal 5'-phosphate synthase lyase & NS & NS \\
\hline Q816H9 & $\underline{71}$ & MenB & 1,4-dihydroxy-2-naphthoyl-CoA synthase & NS & NS \\
\hline Q818W9 & $\underline{69}$ & BioD & ATP-dependent dethiobiotin synthetase & NS & NS \\
\hline \multicolumn{6}{|c|}{ Transcription } \\
\hline Q81J18 & $\underline{265}$ & RpoA & $\begin{array}{l}\text { DNA-directed RNA polymerase } \\
\text { subunit alpha }\end{array}$ & NS & NS \\
\hline \multicolumn{6}{|l|}{ Translation } \\
\hline Q814C4 & 138 & Tuf & Elongation factor Tu & NS & NS \\
\hline \multicolumn{6}{|c|}{ Nucleotide metabolism } \\
\hline Q81JC8 & 327 & GuaB & $\begin{array}{l}\text { Inosine-5'-monophosphate } \\
\text { dehydrogenase }\end{array}$ & NS & NS \\
\hline \multicolumn{6}{|c|}{ Defense mechanisms } \\
\hline Q81IK9 & 166 & AhpC & Alkyl hydroperoxide reductase $C$ & NS & NS \\
\hline \multicolumn{6}{|c|}{ Lipid and Fatty acid metabolism } \\
\hline Q814Y7 & $\underline{91}$ & FabZ & $\begin{array}{l}\text { 3-hydroxyacyl-[acyl-carrier-protein] } \\
\text { dehydratase }\end{array}$ & NS & NS \\
\hline$\underline{\mathrm{Q} 816 \mathrm{~B} 6}$ & $46 / 49$ & NfuA (Yutl) & NifU protein & -1.9 & $-1,68$ \\
\hline Q816D2 & 117 & & HESB protein & NS & NS \\
\hline \multicolumn{6}{|c|}{ Secondary metabolites biosynthesis, transport and catabolism } \\
\hline$\underline{\text { Q81DQ3 }}$ & 14 & DhbC & Isochorismate synthase & -2.71 & -3.06 \\
\hline$\underline{\text { Q1DQ1 }}$ & 67 & DhbB & Isochorismatase & -2.55 & -2.52 \\
\hline \multicolumn{6}{|c|}{ Energy production and conversion } \\
\hline Q814U7 & $\underline{135}$ & & $\begin{array}{l}\text { Nitrilotriacetate monooxygenase } \\
\text { component B }\end{array}$ & NS & NS \\
\hline
\end{tabular}




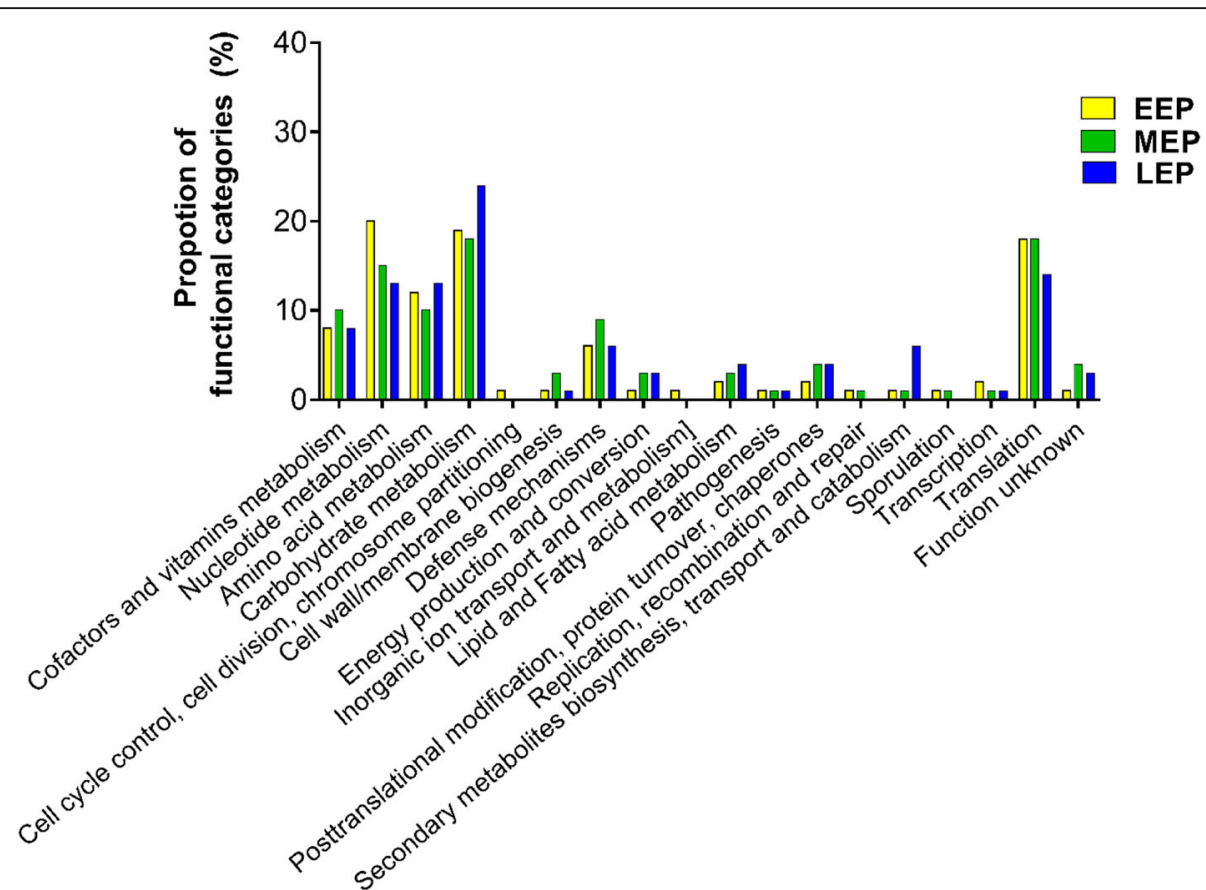

Fig. 6 Functional categorization of reactive Cys-containing proteins at early (EEP), mid (MEP) and late (LEP) exponential growth stages

Overall, redox-sensitive Cys residues were mainly detected in their reduced forms, according to the reducing environment of cytoplasm [35], and the extracellular milieu in our condition. Only two Cys residues were detected more frequently as OxCys than as RedCys. In addition to being dependent of cellular conditions, the reactivity of Cys residues is partly controlled by the intrinsic properties of the sulfur atom and by the position of the Cys residue in the three-dimensional protein structure [42, 43]. Reactivity can also be modulated by proximity to a metal ion [44]. Interestingly, the two Cys residues, which were mainly detected as OxCys in our samples both belonged to alcohol dehydrogenase AdhA (Q81DX6). The predicted three-dimensional structure of the protein (data not shown) localizes these two residues, $\mathrm{Cys}^{91}$ and $\mathrm{Cys}^{97}$, near a $\mathrm{Zn}^{2+}$ binding site, which is assumed to promote oxidation [45].

Several redox-sensitive Cys-containing proteins identified in this study (Adk, PpaC, PurL, GuaB) were previously reported to undergo thiol modifications under oxidizing conditions in Bacillus subtilis, Staphylococcus aureus, Corynebacterium glutamicum, and E. coli $[27,28,46,47]$. These reports suggest that these proteins could undergo specific redox regulation in response to variations in environmental conditions.

Our results showed that the high detection of RedCys residues at LEP was due to differences in abundance for 8 Cys-containing proteins (including 3 Cys-containing proteins that were detected exclusively at LEP) and the detection of 21 Cys-containing proteins with a higher number of RedCys at LEP without abundance variation. Therefore, the growth-phase-specificity of $B$. cereus thiol proteome may be explained both by a change of proteome composition and a distinct redox sensitivity of Cys residues in individual proteins [48]. The results of the Panther Gene Ontology analysis (http://geneontology. org/) illustrated the composition changes of B. cereus proteome (Figure S3). This analysis showed an enrichment of proteome in proteins involved in siderophore biosynthesis, and tryptophan biosynthesis at LEP, at the expense of proteins involved in deoxyribonucleotide biosynthesis. No proteome change characterizing the onset of sporulation has been detected, according to previous work [49].

Many abundant Cys-proteins, such as those involved in carbohydrate metabolism (PtsI and PfkA) and translation (FusA and Tuf), harbored cysteines displaying an increasing RedCys residues as growth progressed. These results suggest that these proteins may be redoxregulated to ensure efficient glucose uptake and protein biosynthesis over the course of growth. Moreover, redox regulation of PtsI and PfkA could potentially divert the metabolic flux toward post-translational modifications [50]. Interestingly, the modifications observed on $\mathrm{Cys}^{82}$ and $\mathrm{Cys}^{138}$ in the elongation factor Tuf at MEP, and LEP, respectively, could reflect two different sites of potential redox regulation during anaerobic growth. A growth-phase-dependent modification of Cys residues in Tuf could be the result of a growth-phase-dependent regulation network, as previously described $[51,52]$. The 
redox-sensitive Cys residues in the Tuf protein were previously described to be S-bacillithiolated and Smycothiolated in response to hypochlorite stress [28, 53]. In addition, $\mathrm{Cys}^{82}$ in Tuf was identified as a conserved S-bacillithiolated site among Bacillus spp. and Staphylococcus carnosus [54].

Our data showed that some redox-sensitive Cyscontaining proteins were detected during LEP, due to their high abundance at this stage of growth, such as Kat, NifU, DhbC, and DhbB, which had at least one Cys detected mainly as RedCys during LEP. From a physiological point of view, these data support the entry of bacteria into the stationary phase $[55,56]$ in response to stress and nutrient starvation. The Fe-S-containing protein NifU is involved in sensing iron and superoxide levels [57], catalase is produced to deal with oxidative stress [58], and the enzymes involved in bacillibactin biosynthesis circumvent iron starvation [56]. To our knowledge, this is the first study to demonstrate the presence of reactive cysteine residues in DhbC and DhbB. Redox regulation of DhbB (Q81DQ1) remains uncharacterized, but might be important since this enzyme uses a thiolation mechanism to activate siderophore assembly [59].

\section{Conclusions}

In summary, we presented an overview of the $B$. cereus ATCC 14579 thiol proteome, which is mainly defined by a subset of redox-sensitive Cys residues differing from one growth stage to another, and functionally related to growth-stage-dependent cellular events. This works represents an essential step for researchers in the fields of bacterial physiology toward understanding and predicting the effect of changing redox conditions.

\section{Methods}

\section{Chemicals}

Trichloroacetic acid (TCA), dithiothreitol (DTT), Trifluoroacetic acid (TFA), and iodoacetamide (IAM) were purchased from Sigma (St-Quentin-Fallavier, France). N-ethylmaleimide (NEM) and bicinchoninic acid assay (BCA) were purchased from Fisher Scientific (France). Trypsin and ProteaseMax reagent used for proteolysis were purchased from Promega (France).

\section{Regulated batch culture}

B. cereus was grown in regulated batch conditions $(\mathrm{pH} 7$, temperature $\left.=37^{\circ} \mathrm{C}, \mathrm{pO}_{2}=0 \%\right)$ in MOD medium supplemented with $30 \mathrm{mM}$ glucose [6]. Briefly, B. cereus ATCC 14579 strain [60] was grown in batch cultures under anoxic conditions in a 3-L-capacity bioreactor (My-control, Applikon technology) equipped with a $\mathrm{pH}$ electrode (405-DPAS-SC-K8S/225, Mettler Toledo), a $\mathrm{pO}_{2}$ polarographic oxygen electrode (Z010023525, Applisens), and an AgCl ORP electrode (pT4805-SC-DPAS-K8S/225,
Mettler Toledo). All batch culture experiments were conducted in $2 \mathrm{~L}$ MOD medium supplemented with $30 \mathrm{mM}$ glucose, as described previously [29]. Continuous sparging of pure $\mathrm{N}_{2}(10 \mathrm{~L} / \mathrm{h})$ was maintained to generate anoxic conditions $\left(\mathrm{pO}_{2}=0 \%\right)$. Cultures were stirred at $300 \mathrm{rpm}$, and temperature was set to $37^{\circ} \mathrm{C}$. The $\mathrm{pH}$ of the cell culture medium was maintained at 7 by adding $1 \mathrm{M} \mathrm{HCl}$ and $3 \mathrm{M} \mathrm{KOH}$.

$B$. cereus cultures were performed in biological triplicates and the optical density (OD) at $600 \mathrm{~nm}$ was measured every $30 \mathrm{~min}$. ORP values were corrected based on the value recorded by the reference electrode $(+207 \mathrm{mV}$ at $\left.37^{\circ} \mathrm{C}\right)$. The specific maximum growth rate $\left(\mu_{\max }\right)$ was determined using the Zwietering growth model [61].

\section{Protein extraction: quenching cellular thiol-disulfide exchange}

Culture extracts were harvested anaerobically during the early-exponential growth phase (EEP) (at $\mu_{\max }$ ), midexponential growth phase (MEP), and late-exponential growth phase (LEP) in vials containing $25 \%$ trichloroacetic acid (TCA). Extracts were incubated with TCA overnight at $-20{ }^{\circ} \mathrm{C}$ to maximize protein precipitation. Proteins were pelleted by centrifugation $(13,800 \mathrm{x}$ g, $15 \mathrm{~min}, 4^{\circ} \mathrm{C}$ ) and washed twice with ice-cold acetone to remove excess TCA. Supernatants were discarded, and protein pellets were air-dried.

\section{Differential thiol trapping method}

Differential thiol labeling was performed as described previously [32, 62], with minor modifications. Briefly, protein extracts resuspended in denaturing buffer were divided between two tubes, labeled IDN, and IN (Fig. 2). Free cysteine residues were alkylated with $50 \mathrm{mM}$ iodoacetamide (IAM), at room temperature in the dark for 1 h. Proteins were precipitated once again with $25 \%(\mathrm{w} / \mathrm{v})$ TCA and washed twice with ice-cold acetone. Protein pellets were resuspended in the same buffer, and the IN samples were incubated with $150 \mathrm{mM} \mathrm{N}$-ethylmaleimide (NEM). IDN samples were first reduced by adding 25 $\mathrm{mM}$ dithiothreitol (DTT), and incubating at room temperature for $1 \mathrm{~h}$. Reduced proteins were TCA precipitated (25\%), and resuspended before alkylation with 150 mM NEM.

The protein concentration of each sample was estimated using the bicinchoninic acid assay (BCA), according to the manufacturer's protocol (Thermo-Fisher). A $90-\mu$ g aliquot of proteins was loaded onto a $12 \%$ SDSPAGE for a short migration at $90 \mathrm{~V}$ (15-20 min). Gels were stained with imperial ${ }^{\mathrm{TM}}$ protein stain (ThermoFisher) for $1 \mathrm{~h}$ and destained with water. Protein bands were excised from gels. IDN and IN samples were digested with trypsin using the ProteaseMax surfactant (Promega) as described elsewhere [63] without further 
reduction/alkylation. For all samples, the resulting peptide mixtures were dissolved in $0.1 \%$ trifluoroacetic acid (TFA) prior to nano LC-MS/MS analyses.

\section{High-resolution tandem mass spectrometry}

Peptides were identified using a Q-Exactive HF mass spectrometer (Thermo Scientific) coupled to an ultimate 3000 nano LC system (Thermo Scientific). The system was essentially operated as previously described [64] with minor modifications. The peptide mixtures $(10 \mu \mathrm{L})$ were loaded and desalted online on a reverse-phase precolumn (Acclaim Pepmap $100 \mathrm{C} 185 \mu \mathrm{m}$ bead size, $100-\AA$ pore size, $5 \mathrm{~mm} \times 300 \mu \mathrm{m}$, Thermo). They were then resolved on a nanoscale Acclaim Pepmap 100 C18 column $(3 \mu \mathrm{m}$ bead size, $100-\AA$ pore size, $15 \mathrm{~cm} \times$ $75 \mu \mathrm{m})$ at a flow rate of $200 \mathrm{nl} / \mathrm{min}$ using a $120-\mathrm{min}$ gradient combining buffer $\mathrm{B}\left(0.1 \% \mathrm{HCOOH}, 80 \% \mathrm{CH}_{3} \mathrm{CN}\right)$ and buffer $\mathrm{A}\left(0.1 \% \mathrm{HCOOH}, 100 \% \mathrm{H}_{2} \mathrm{O}\right): 4-25 \% \mathrm{~B}$ in $100 \mathrm{~min}$, followed by $25-40 \% \mathrm{~B}$ in $20 \mathrm{~min}$. The mass spectrometer was operated in the Top20 data-dependent acquisition mode with full MS scans acquired from 350 to $1800 \mathrm{~m} / \mathrm{z}$ at 60,000 resolution, and after each scan, selection of the 20 most abundant precursor ions for fragmentation and MS/MS acquisition at 15,000 resolution. An intensity threshold of $9 \times 10^{4}$ was applied. A 10-s dynamic exclusion was used to increase the detection of low-abundance peptides. Only double- and triple-charged ions were selected for MS/MS analysis.

\section{MS/MS spectra interpretation}

MS/MS spectra were queried against the theoretical $B$. cereus ATCC 14579 proteome (5216 sequences) with the Mascot Daemon software, version 2.6.1 (Matrix Science). The parameters were: full trypsin specificity, only $2+$ and $3+$ peptide charges, a mass tolerance of $5 \mathrm{ppm}$ on the parent ion, a mass tolerance of $0.02 \mathrm{Da}$ on the MS/MS ions, a maximum of two missed cleavages, no static modifications, and dynamic modifications were $\mathrm{N}$ ethylmaleimide (C), Carbamidomethyl (C), Carbamyl $(\mathrm{K})$, Oxidation $(\mathrm{M})$, Deamidation (NQ). All peptide matches with a peptide score associated with a $p$-value of less than 0.05 were parsed using IRMa $1.31 .1 \mathrm{c}$ software [65]. Proteins were considered valid when at least two different peptides were detected in the same sample. The proteomics datasets were submitted to the ProteomeXchange Consortium via the PRIDE partner repository [66], under dataset identifiers PXD022049 and https://doi.org/10.6019/PXD022049. [The dataset can be accessed with the Username: reviewer_pxd022049@ebi. ac.uk and Password: NFX3eY3n].

\section{Data analysis}

All experiments were replicated three times. For each Cys residues, we compared the mean value of the number of reduced Cys residues with the mean value of the number of oxidized Cys residues. Statistical analysis was performed using the paired Student t-test, setting the threshold for statistical significance at $p$ less than 0.05. For proteome profiling, data were normalized relative to the total spectral count. Protein abundances were compared between two growth stages, as previously described [67]. Proteins for which abundances changed by more than 1.5 were considered significant when the $p$-value was less than 0.05 . Protein functions were assigned based on information from the Clusters of Orthologous Groups (COG) database [68].

\section{Supplementary Information}

The online version contains supplementary material available at https://doi. org/10.1186/s12864-021-07962-y.

Additional file 1: Table S1. Non-redundant Cys-peptides identified in samples harvested at EEP, MEP, and LEP, in the IDNc dataset. Table S2.

List of 117 Cys-proteins identified. From column Q to V: abundance levels of Cys-proteins (log2 values of spectral counts for each protein with the adjusted $p$-value).

Additional file 2: Figure S3. Changes in B. cereus proteome composition between EEP, MEP, and LEP obtained by Gene Ontology analysis of pathway enrichment.

\section{Acknowledgments}

The authors would like to thank the Algerian government for supporting Fella Hamitouche's thesis fellowship. We are also grateful to Bénédicte Doublet for technical assistance and to Joëlle Vinh and Vincent Méjean for helpful discussions.

Authors' contributions

CD and LD conceived and designed the experiments. FH and JCG performed the experiments. JA, JCG, and PS contributed (reagents/materials/ analysis tools). FH, JCG, JA, CD, and LD analyzed the data. FH, CD, and LD wrote the paper. All authors reviewed the manuscript. The authors read and approved the final manuscript.

\section{Funding}

This work was supported by Avignon-Université and the Algerian government.

\section{Availability of data and materials}

All data and materials are fully available without restriction. The proteomics datasets were submitted to the ProteomeXchange Consortium via the PRIDE partner repository [Project accession: PXD022049; Project DOI: https://doi.org/10.6019/ PXD022049] and can be accessed at the URL [https://www.ebi.ac.uk/pride/login] with the Username: reviewer_pxd022049@ebi.ac.uk and Password: NFX3eY3n.

\section{Declarations}

Ethics approval and consent to participate

'Not applicable'.

\section{Consent for publication}

'Not applicable'.

\section{Competing interests}

The authors declare that they have no competing interests.

\section{Author details}

'Avignon Université, INRAE, UMR SQPOV, Site Agroparc, F-84914 Avignon

Cedex 9, France. ${ }^{2}$ Université Paris-Saclay, CEA, INRAE, Département

Médicaments et Technologies pour la Santé (DMTS), SPI, 30200

Bagnols-sur-Cèze, France. 
Received: 23 March 2021 Accepted: 5 August 2021

Published online: 07 September 2021

\section{References}

1. Ehling-Schulz M, Fricker M, Scherer S. Identification of emetic toxin producing Bacillus cereus strains by a novel molecular assay. FEMS Microbiol Lett. 2004;232(2):189-95.

2. Duport $C$, Jobin M, Schmitt P. Adaptation in Bacillus cereus: from stress to disease. Front Microbiol. 2016;7:1550.

3. Jeßberger N, Rademacher C, Krey VM, Dietrich R, Mohr A-K, Böhm M-E, et al. Simulating intestinal growth conditions enhances toxin production of enteropathogenic Bacillus cereus. Front Microbiol. 2017;8:627.

4. Diomande SE, Guinebretière $\mathrm{M}-\mathrm{H}$, Broussolle V, Brillard J. Role of fatty acids in Bacillus environmental adaptation. Front Microbiol. 2015;6:813.

5. Rosenfeld E, Duport C, Zigha A, Schmitt P. Characterization of aerobic and anaerobic vegetative growth of the food-borne pathogen Bacillus cereus F4430/73 strain. Can J Microbiol. 2005;51(2):149-58.

6. Zigha A, Rosenfeld E, Schmitt P, Duport C. Anaerobic cells of Bacillus cereus F4430/73 respond to low oxidoreduction potential by metabolic readjustments and activation of enterotoxin expression. Arch Microbiol. 2006;185(3):222-33.

7. Agledal L, Niere M, Ziegler M. The phosphate makes a difference: cellular functions of NADP. Redox Rep. 2010;15(1):2-10.

8. Xiao W, Wang RS, Handy DE, Loscalzo J. NAD $(H)$ and NADP $(H)$ redox couples and cellular energy metabolism. Antioxid Redox Signal. 2018;28(3): 251-72.

9. Reniere ML. Reduce, Induce, Thrive: Bacterial Redox Sensing during Pathogenesis. J Bacteriol. 2018;200(17):e00128-18.

10. Poole LB. The basics of thiols and cysteines in redox biology and chemistry. Free Radic Biol Med. 2015;80:148-57.

11. Noiva R. Enzymatic catalysis of disulfide formation. Protein Expr Purif. 1994; 5(1):1-13.

12. Giles NM, Watts AB, Giles Gl, Fry FH, Littlechild JA, Jacob C. Metal and redox modulation of cysteine protein function. Chem Biol. 2003;10(8):677-93.

13. Yang J, Carroll KS, Liebler DC. The expanding landscape of the thiol redox proteome. Mol Cell Proteomics. 2016;15(1):1-11.

14. Chiappetta G, Ndiaye S, Igbaria A, Kumar C, Vinh J, Toledano MB. Proteome screens for Cys residues oxidation: the redoxome. Methods Enzymol. : Elsevier. 2010;473:199-216.

15. Ellman GL. Tissue sulfhydryl groups. Arch Biochem Biophys. 1959;82(1):70-7.

16. Lee S-R, Kwon K-S, Kim S-R, Rhee SG. Reversible inactivation of proteintyrosine phosphatase 1B in A431 cells stimulated with epidermal growth factor. J Biol Chem. 1998;273(25):15366-72.

17. Wojdyla K, Rogowska-Wrzesinska A. Differential alkylation-based redox proteomics--lessons learnt. Redox Biol. 2015;6:240-52.

18. Le Moan N, Clement G, Le Maout S, Tacnet F, Toledano MB. The Saccharomyces cerevisiae proteome of oxidized protein thiols contrasted functions for the thioredoxin and glutathione pathways. J Biol Chem. 2006; 281(15):10420-30.

19. Baty JW, Hampton MB, Winterbourn CC. Detection of oxidant sensitive thiol proteins by fluorescence labeling and two-dimensional electrophoresis. Proteomics: International Edition. 2002;2(9):1261-6.

20. Wojdyla K, Williamson J, Roepstorff P, Rogowska-Wrzesinska A. The SNO/ SOH TMT strategy for combinatorial analysis of reversible cysteine oxidations. J Proteome. 2015;113:415-34.

21. Guo J, Nguyen AY, Dai Z, Su D, Gaffrey MJ, Moore RJ, et al. Proteome-wide light/dark modulation of thiol oxidation in cyanobacteria revealed by quantitative site-specific redox proteomics. Mol Cell Proteomics. 2014;13(12): 3270-85.

22. Ansong C, Sadler NC, Hill EA, Lewis MP, Zink EM, Smith RD, et al. Characterization of protein redox dynamics induced during light-to-dark transitions and nutrient limitation in cyanobacteria. Front Microbiol. 2014;5:325.

23. Sievers S, Dittmann S, Jordt T, Otto A, Hochgräfe F, Riedel K. Comprehensive redox profiling of the thiol proteome of Clostridium difficile. Mol Cell Proteomics. 2018;17(5):1035-46.

24. Brandes N, Reichmann D, Tienson H, Leichert LI, Jakob U. Using quantitative redox proteomics to dissect the yeast redoxome. J Biol Chem. 2011;286(48): 41893-903.

25. Shakir S, Vinh J, Chiappetta G. Quantitative analysis of the cysteine redoxome by iodoacetyl tandem mass tags. Anal Bioanal Chem. 2017; 409(15):3821-30.
26. Leichert LI, Gehrke F, Gudiseva HV, Blackwell T, Ilbert M, Walker AK, et al. Quantifying changes in the thiol redox proteome upon oxidative stress in vivo. Proc Natl Acad Sci. 2008;105(24):8197-202.

27. Chi BK, Gronau K, Mäder U, Hessling B, Becher D, Antelmann H. S-bacillithiolation protects against hypochlorite stress in Bacillus subtilis as revealed by transcriptomics and redox proteomics. Mol Cell Proteomics. 2011;10(11).

28. Imber M, Pietrzyk-Brzezinska AJ, Antelmann H. Redox regulation by reversible protein S-thiolation in gram-positive bacteria. Redox Biol. 2019;20:130-45.

29. Madeira JP, Alpha-Bazin B, Armengaud J, Duport C. Time dynamics of the Bacillus cereus exoproteome are shaped by cellular oxidation. Front Microbiol. 2015;6:342.

30. Madeira J-P, Armengaud J, Duport C. Methionine residues in exoproteins and their recycling by methionine sulfoxide reductase $A B$ serve as an antioxidant strategy in Bacillus cereus. Front Microbiol. 2017;8:1342.

31. Chiappetta G, Ndiaye S, Igbaria A, Kumar C, Vinh J, Toledano MB. Proteome Screens for Cys Residues Oxidation. Methods Enzymol. 2010;473:199-216.

32. Kuo Y-H, Konopko AM, Borotto NB, Majmudar JD, Haynes SE, Martin BR. Profiling protein S-sulfination with maleimide-linked probes. Chembiochem. 2017;18(20):2028.

33. Bernhardt J, Weibezahn J, Scharf C, Hecker M. Bacillus subtilis during feast and famine: visualization of the overall regulation of protein synthesis during glucose starvation by proteome analysis. Genome Res. 2003;13(2): 224-237.

34. Blanc B, Gerez C, Ollagnier de Choudens S. Assembly of Fe/S proteins in bacterial systems: biochemistry of the bacterial ISC system. Biochim Biophys Acta. 2015;1853(6):1436-47.

35. Leichert LI, Jakob U. Protein thiol modifications visualized in vivo. PLoS Biol. 2004;2(11):e333.

36. Hansen RE, Winther JR. An introduction to methods for analyzing thiols and disulfides: reactions, reagents, and practical considerations. Anal Biochem. 2009:394(2):147-58.

37. Daniels R, Mellroth P, Bernsel A, Neiers F, Normark S, von Heijne G, et al. Disulfide bond formation and cysteine exclusion in gram-positive bacteria. J Biol Chem. 2010;285(5):3300-9.

38. Knoefler D, Thamsen M, Koniczek M, Niemuth NJ, Diederich AK, Jakob U. Quantitative in vivo redox sensors uncover oxidative stress as an early event in life. Mol Cell. 2012;47(5):767-76.

39. Jacob H. Redox potential. Methods Microbiol. 1970;2:91-123.

40. Michelon D, Abraham S, Ebel B, De Coninck J, Husson F, Feron G, et al. Contribution of exofacial thiol groups in the reducing activity of Lactococcus lactis. FEBS J. 2010;277(10):2282-90.

41. Pillot G, Brillet-Viel A, Prévost H. Implication of exofacial thiol groups in the reducing activity of Listeria monocytogenes. bioRxiv. 2018:353409. https://doi. org/10.1101/353409.

42. Fowler NJ, Blanford CF, de Visser SP, Warwicker J. Features of reactive cysteines discovered through computation: from kinase inhibition to enrichment around protein degrons. Sci Rep. 2017;7(1):16338.

43. Netto LE, de Oliveira MA, Monteiro G, Demasi AP, Cussiol JR, Discola KF, et al. Reactive cysteine in proteins: protein folding, antioxidant defense, redox signaling and more. Comp Biochem Physiol Toxicol Pharmacol. 2007; 146(1-2):180-93.

44. Stewart MD, Igumenova TI. Reactive cysteine in the structural Zn2+ site of the C1B domain from PKCa. Biochemistry. 2012;51(37):7263-77.

45. Tamarit J, Cabiscol E, Ros J. Identification of the major oxidatively damaged proteins in Escherichia coli cells exposed to oxidative stress. J Biol Chem. 1998;273(5):3027-32.

46. Loi W, Rossius M, Antelmann $H$. Redox regulation by reversible protein S-thiolation in bacteria. Front Microbiol. 2015;6:187.

47. Xie K, Bunse C, Marcus K, Leichert LI. Quantifying changes in the bacterial thiol redox proteome during host-pathogen interaction. Redox Biol. 2019;21:101087.

48. Go Y-M, Chandler JD, Jones DP. The cysteine proteome. Free Radic Biol Med. 2015;84:227-45.

49. Abbas AA, Planchon S, Jobin M, Schmitt P. Absence of oxygen affects the capacity to sporulate and the spore properties of Bacillus cereus. Food Microbiol. 2014;42:122-31.

50. Ralser M, Wamelink MM, Latkolik S, Jansen EE, Lehrach $H$, Jakobs C. Metabolic reconfiguration precedes transcriptional regulation in the antioxidant response. Nat Biotechnol. 2009;27(7):604-5.

51. Talavera A, Hendrix J, Versées W, Jurènas D, Van Nerom K, Vandenberk N, et al. Phosphorylation decelerates conformational dynamics in bacterial translation elongation factors. Sci Adv. 2018;4(3):eaap9714. 
52. Kraal B, Lippmann C, Kleanthous C. Translational regulation by modifications of the elongation factor Tu. Folia Microbiol. 1999:44(2):131-41.

53. Chi BK, Busche T, Van Laer K, Bäsell K, Becher D, Clermont L, et al. Protein Smycothiolation functions as redox-switch and thiol protection mechanism in Corynebacterium glutamicum under hypochlorite stress. Antioxid Redox Signal. 2014;20(4):589-605.

54. Chi BK, Roberts AA, Huyen TTT, Bäsell K, Becher D, Albrecht D, et al. Sbacillithiolation protects conserved and essential proteins against hypochlorite stress in firmicutes bacteria. Antioxid Redox Signal. 2013;18(11): 1273-95.

55. Jaishankar J, Srivastava P. Molecular basis of stationary phase survival and applications. Front Microbiol. 2017;8:2000.

56. Lee JY, Passalacqua KD, Hanna PC, Sherman DH. Regulation of petrobactin and bacillibactin biosynthesis in Bacillus anthracis under iron and oxygen variation. PLoS One. 2011:6(6):e20777.

57. Fontecave M. Iron-sulfur clusters: ever-expanding roles. Nat Chem Biol. 2006; 2(4):171-4.

58. Heo YJ, Chung IY, Cho WJ, Lee BY, Kim JH, Choi KH, et al. The major catalase gene (katA) of Pseudomonas aeruginosa PA14 is under both positive and negative control of the global transactivator OxyR in response to hydrogen peroxide. J Bacteriol. 2010;192(2):381-90.

59. May JJ, Wendrich TM, Marahiel MA. The dhb operon of Bacillus subtilis encodes the biosynthetic template for the catecholic siderophore 2,3dihydroxybenzoate-glycine-threonine trimeric ester bacillibactin. J Biol Chem. 2001;276(10):7209-17.

60. Ivanova N, Sorokin A, Anderson I, Galleron N, Candelon B, Kapatral V, et al. Genome sequence of Bacillus cereus and comparative analysis with Bacillus anthracis. Nature. 2003;423(6935):87-91.

61. Zwietering M, Jongenburger I, Rombouts F, Van't Riet K. Modeling of the bacterial growth curve. Appl Environ Microbiol. 1990;56(6):1875-81.

62. Wholey $W-Y$, Jakob U. Hsp33 confers bleach resistance by protecting elongation factor Tu against oxidative degradation in vibrio cholerae. Mol Microbiol. 2012;83(5):981-91.

63. de Groot A, Dulermo R, Ortet P, Blanchard L, Guérin P, Fernandez B, et al. Alliance of proteomics and genomics to unravel the specificities of Sahara bacterium Deinococcus deserti. PLoS Genet. 2009;5(3).

64. Klein G, Mathé C, Biola-Clier M, Devineau S, Drouineau E, Hatem E, et al. RNA-binding proteins are a major target of silica nanoparticles in cell extracts. Nanotoxicology. 2016;10(10):1555-64.

65. Dupierris V, Masselon C, Court M, Kieffer-Jaquinod S, Bruley C. A toolbox for validation of mass spectrometry peptides identification and generation of database: IRMa. Bioinformatics. 2009;25(15):1980-1.

66. Perez-Riverol Y, Csordas A, Bai J, Bernal-Llinares M, Hewapathirana S, Kundu DJ, et al. The PRIDE database and related tools and resources in 2019: improving support for quantification data. Nucleic Acids Res. 2019;47(D1): D442-D50.

67. Rousset L, Alpha-Bazin B, Château A, Armengaud J, Clavel T, Berge O, et al. Groundwater promotes emergence of asporogenic mutants of emetic Bacillus cereus. Environ Microbiol. 2020;22(12):5248-64.

68. Galperin MY, Makarova KS, Wolf YI, Koonin EV. Expanded microbial genome coverage and improved protein family annotation in the COG database. Nucleic Acids Res. 2015;43(D1):D261-D9.

\section{Publisher's Note}

Springer Nature remains neutral with regard to jurisdictional claims in published maps and institutional affiliations.

Ready to submit your research? Choose BMC and benefit from:

- fast, convenient online submission

- thorough peer review by experienced researchers in your field

- rapid publication on acceptance

- support for research data, including large and complex data types

- gold Open Access which fosters wider collaboration and increased citations

- maximum visibility for your research: over $100 \mathrm{M}$ website views per year

At BMC, research is always in progress.

Learn more biomedcentral.com/submissions 